\title{
Život po maturite alebo o hodnotách vzdelania u žiakov stredných škôl
}

\author{
Lukáš Bomba \\ Žilinská univerzita v Žiline, Fakulta humanitných vied, Katedra pedagogických štúdií
}

Redakci zasláno 13. 2. 2014 / upravená verze obdržena 18. 8. 2014 /

k uveřejnění přijato 19. 8. 2014

\begin{abstract}
Abstrakt: Predložený text je pokusom o reflexiu súčasných významov školského vzdelávania pre žiakov stredných škôl. Cielom je identifikovat' hodnoty vzdelania žiakov stredných škôl a zároveň hladat' v rozprávaniach žiakov prítomnost' kultúrnych dimenzií neoliberalizmu, špecificky riadenie sa princípmi toho, čo nazývame neoliberálna guvernmentalita. V úvodných častiach textu autor v krátkosti osvetluje tie časti teórie neoliberálnej guvernmentality, ktoré neskôr vo výskumnej časti považuje za t'ažiskové pre interpretáciu rozhovorov so žiakmi stredných škôl. Autor ukazuje, že základné pojmy v diskurze života po ukončení strednej školy maturitnou skúškou sú šikovnost' a presadenie sa. Uvedené pojmy používajú žiaci na vysvetlenie úspechu jednotlivca v živote. $V$ závere autor ukazuje, že žiaci nerozmýšlajú o výbere vysokej školy pre dalšiie vzdelávanie sa na základe jednoznačných budúcich profitov, ale ked’že život po ukončení strednej školy je chápaný ako projekt cesty za individuálnym št’astím, aj výber vysokej školy je podriadený takémuto zmýšlaniu.
\end{abstract}

Klúčové slová: maturita, stredná škola, neoliberalizmus, neoliberálna guvernmentalita, vysoká škola

Prečo je dnes vzdelanie vnímané ako dôležité pre úspech jednotlivca v živote? Neustále stúpa počet ludí vo vzdelávacích systémoch spoločností, ktorí nakoniec dosahujú najvyššie teda vysokoškolské vzdelanie. Musí teda existovat' motivácia, ktorá ženie mnohých za dosiahnutím vysokoškolského vzdelania. Je úplne samozrejmé, že motivácia nikdy nie je výhradná a nemá jeden ciel'. Motiváciou pre vysokoškolské štúdium je, napríklad v prípade medicíny minimálne ochota pomáhat' druhým, $v$ prípade pedagogiky zase možno láska k det'om a ich výchove a vzdelávaniu. Avšak vždy za explicitným môžeme hladat' latentné obsahy toho, čo vysokoškolské vzdelávanie reprezentuje.

Pokúsim sa v tomto príspevku ukázat', že zmeny vo vzdelávacom systéme majú svoje dôsledky aj v každodennosti školy a žiakov v škole. Vychádzam z, 
dnes v pedagogike stále viac sa presadzujúceho, konceptu neoliberálnej guvernmentality, ktorý čerpá z Foucaultovho diela, a to predovšetkým z predpokladu, že logika neoliberalizmu kolonizuje tie oblasti l'udského života, kde pred tým nebola. Tento koncept, zasadený do problematiky vzdelávania a výchovy, opisuje neoliberalizmus ako dominantný v súčasnom vzdelávaní a vo výchove, pretože sa nejedná výhradne o jeho inštitucionalizované školské formy, ktoré premieňa. Na kvalitatívnom výskume so žiakmi stredných škôl demonštrujem, ako sa ekonomický diskurz udomácnil v rozmýšlaní o sebe a o druhých $\mathrm{v}$ diskurze vzdelania a vzdelávania. Je potrebné nakoniec priznat', že v rámci širšieho kontextu ako je slovenský, sa podobné výskumy už uskutočnili. Na Slovensku, a rovnako tak aj v Čechách, nebol zatial' tejto téme vo výskume venovaný výraznejší priestor.

\section{Kontext súčasného vzdelávania}

V poslednom polstoročí mnohí ukázali, že vzdelávanie v jeho inštitucionalizovanej podobe produkuje, alebo reprodukuje spoločenské nerovnosti. Bernstein $(1971,1977)$ výskumom ukázal, že školy používajú odlišné kurikulá a výchovno-vzdelávacie metódy $\mathrm{v}$ rôznych druhoch škôl $\mathrm{v}$ závislosti od toho, či školu navštevovali deti strednej triedy alebo deti pracujúcej triedy. Vysvetlenie sociálnych nerovností hladá Bernstein medzi rodinou a jej triednou pozíciou a zároveň v systéme významov, ktoré rodina a jej členovia, ako súčast' konkrétnej spoločenskej triedy, používajú vo svojom jazyku. Bourdieu $(1977,1998)$ vložil problém nerovností v škole do rámca, habitusu a reprodukcie kapitálu. Rôzne druhy kapitálu tým, že sú zamenitel'né, umožňujú získavat' vzdelanie jednotlivcovi, ktoré môže zase poslúžit' ako kapitál, a ktoré je možné investovat' a neskôr čerpat' z tejto investície výhody. Apple (1990) zase skúmal a skúma nerovnosti ako dôsledok triedne nastaveného kurikula v školách. Apple pritom špeciálne neodlišuje formálne a skryté kurikulum. Obsahy toho, čo sa vyučuje v školách, sú pre Appleho obrazom toho, kto ich napísal, prípadne nechal napísat'. Vyššie triedy vytvárajú pomyselnú mriežku vhodnosti, akceptovatel'nosti, správnosti, prijatel'nosti a pod. konania a správania sa, ktorá je vsadená do učebných osnov a všetci žiaci sú $\mathrm{s}$ ňou konfrontovaní. 
V súčasnosti sa vedie debata o neoliberálnej guvernmentalite vo vzdelávaní a výchove ako u nás ${ }^{1}$, tak aj v zahraničí ${ }^{2}$. Nussbaum (2010) tvrdí, že postupné odsúvanie humanitných a spoločenských vied a umení z univerzít je priamym dôsledkom tlaku ekonomizácie a racionalizácie vzdelávacej sústavy a presadzovaním modelu, v ktorom musí byt' vzdelávacia sústava orientovaná na dosahovanie zisku či rentabilitu vzdelávania meranú hospodársky. Existujú tendencie a snahy ekonomickým diskurzom presadzovat' také videnie vzdelávania, ktoré musí byt' predovšetkým hospodársky výhodné. V tomto diskurze absentujú také ciele vzdelávania ako humanizmus, záujem o druhých, demokracia ako hodnota či láska ku vzdelaniu.

Resnik (2012, s. 265) zase vidí v súčasnosti prudký nástup „Vzdelanostnej globalizácie, ktorá implikuje denacionalizáciu vzdelávacích systémov a tak isto znamená proces oslabovania vzdelávacích tradícií, ktoré sa budovali v mnohých prípadoch storočia." Deregulácia a „outsorsovanie“ kompetencií štátov aj v oblasti vzdelávania neznamená väčšiu slobodu v oblasti vzdelávania.. Znamená to len nástup inej regulácie, a to práve tej neoliberálnej. Detailnejší pohl'ad na to, ako štát umožňuje vstup neoliberalizmu do vzdelávania, opisuje napríklad Ho Mok (2010) na príklade Singapuru a Malajzie. Olssen a Peters (2005, s. 313) sa dívajú na neoliberalizmus ako na súčast' procesov globalizácie a hovoria, že $\mathrm{v}$ rámci tohto procesu sa reštrukturalizujú domáce a globálne ekonomické štruktúry. Na pozadí zmien, ktoré vykreslila Sassen (2007) zase môžeme pochopit', akého človeka si žiada neoliberalizmus. V prvom rade je to profesionál, ktorý nie je ukotvený na jednom mieste. Žije v meste, ktorého prostredie tvoria iné globálne mestá a nie primárne mestá v národnom štáte. Do tejto novej vyššej triedy (úspešných) patria predovšetkým, podla Sassen (2007), medzinárodní obchodníci, riadiaci manažment, kontrolné a policajné orgány, rôzni správcovia, politici a d’alší lokálne neukotvení. Tými neúspešnými je predovšetkým nízko platený salariát, ktorý, a to je dôležité, je práve touto svojou povahou súčastou globalizovaného sveta. Ukotvený lokálne v globalizovanom svete. Do vysokej miery môžu potvrdit' pozorovania Sassen (2007) aj Brown a Lauder (2006), ked' sledujú cesty detí elít z medzinárodných škôl cez elitné univerzity až do najvyšších podlaží medzinárodného obchodu. Dnes sa za (relatívne) úspešného človeka teda

Napr. Kaščák a Pupala $(2010,2011,2012)$.

Napr. Amthor a Metzger (2011), Baltodano (2012), Bansel (2007), Brown a Lauder (2006), Davies a Bansel (2007), Holborow (2012), Lakes (2008), Nairn a Higgins (2007), Olssen a Peters (2005), Olssen (2006), Pierce (2012), Sancar a Sancar (2012) a d’alší. 
považujejednotlivec,ktorýsavie presadit',jemobilnýprofesionál,alebonadruhej strane má stabilné zamestnanie, ktoré nie je ohrozené výkyvmi hospodárskych pohybov a/alebo plní prevažne kontrolnú funkciu.

Neoliberálna guvernmentalita práve kvôli prepojeniu nástrojov správy a kultúrnych oprávnení a zaopatrení však neznamená deklarovanú slobodu výberu. Vzdelanie, tak ako je chápané v neoliberálnom diskurze, implikuje aj samotnú svoju podstatu ako „akt prežitia vo vnútri diskurzu praktík riadenia, cez ktoré sú subjekty konštituované ako normálne, rozumejúce a rozpoznávajúce a ich životy sú hodné žitia“"(Bansel, 2007, s. 284). Bansel teda nachádza styčný bod medzi kultúrou a ekonomikou $\mathrm{v}$ neoliberalizme. Diskurz neoliberalizmu, tak ako je vytváraný, hovorí, že pre samotné fyzické prežitie jednotlivca vo svete je nutné byt' vzdelaný, navyše, vzdelanie prináša tým najviac vzdelaným vyššie benefity ako tým menej vzdelaným. Nekonat' v medziach neoliberálnej racionality, znamená teda nekonat' racionálne pre základné l'udské prežitie. Vychádzajúc z Lambeira (2005) je potom možné charakterizovat' pozíciu vzdelávania tak, ako to robí Olssen (2006, s. 223), ked' tvrdí, že nastal posun od vediet' „to“ $k$ vediet' „ako“ a učenie sa takto stáva verejnou zbierkou kompetencií poskytovaných na trhu práce vzdelávacích možností.

Peters a Besley (2006) hovoria o príchode kultúrnej vzdelanostnej ekonomiky (cultural knowledge economy). Takéto chápanie vychádza z konceptu diskurzu vzdelanostnej ekonomiky. Autori sa snažia ukázat' na pozadí prechodu z industriálnej doby do dnešnej informačnej, že vzdelanie, či hodnota vzdelania, je súčastou kultúry, v ktorej žijeme, teda aj praktík správania sa či dosahovania cielov. Na rozdiel od mnohých kritikov neoliberálnych prúdov však autori nehovoria o kolonizácii kultúry ekonomikou, čo je v podstate marxistická téza, ale o kulturalizácii ekonomiky. Príkladom im je vysoko štylizovaná kultúra, kde sú bežné produkty vysoko estetizované a kultúrne vypíňané takým významom, ktorý hovorí o individuálnej identite či módnosti (Peters \& Besly, 2006, s. 28). Skôr ako jednosmerný proces od prispôsobenia sa kultúry trhu sa autori snažia vidiet' kultúru a trh ako vzájomne závislý komplex vztahov. Pohladom neoliberálnej guvernmentality je jednotlivec často pasívnym článkom vysvetlenia. Alebo, ako to hovoria Peters a Besley (2006, s. 59), jednotlivec je „co-producent znalostí, informácií a kultúrnych statkov“.

Chápanieúspešnéhočloveka vyššie uvedenými spôsobmi, alebovšeobecne povedané chápanie človeka ako homo economicus, je symptomatické pre dnešnú dobu. Za individuálnou vôlou k získaniu vzdelania, za inštitucionalizovaným 
kultúrnym kapitálom je obraz úspešného indivídua. Tento obraz (reprezentácia) chce byt' modelom úspešnosti, ktorému je dobré sa priblížit'. Práve k tomuto faktu odkazujú aj Olssen a Peters (2005, s. 324, kurzíva autor), ked' hovoria, že vzdelávanie je kultúrne reprezentované ako systém vstupov a výstupov, ktorý môže byt' zredukovaný na funkciu ekonomickej produkcie.

\section{Výskum: žiaci, význam maturity a hodnota vzdelania}

Patrí to ku koncu tej školy, že si každý urobí tú svoju maturitu. (Saša)

V tejto kapitole bude potrebné ukázat', ako vyzerá diskurz o vzdelaní a práci v stredných školách. Ukazuje sa, že žiaci pracujú so vzájomne prepojenou duálnou schémou úspešnosti človeka v spojení vzdelanie - práca. Tieto dve veci sú závislé jedna od druhej, podmieňujú sa a jedna bez druhej nemá význam. A stráca zmysel, pokial' sa neobjavuje v diskurzívnom páre so svojou, takpovediac dvojičkou. Jednoducho povedané, stalo sa to, že pokial' modernita vytvorením a zavedením školskej dochádzky pre deti do určitej miery oddelila a stanovila svet dospelých a svet detí, svet zarábajúcich a svet učenia sa, tak dnešná doba práce zvýrazňuje túto prepojenost'.

Uskutočnil som výskum ${ }^{3}$, ktorý sa zameriaval na význam maturity v dnešnej dobe. Jeho ciel'om bolo nájst' odpovede na otázky, aká je hodnota vzdelania pre žiakov stredných škôl, aký význam má maturita pre d’alší život žiaka a aký diskurz vedú žiaci stredných škôl o práci, štúdiu a vzdelávaní. Výskum prebiehal formou interview so skupinami žiakov v dvoch školách. Prvou školou bola obchodná akadémia a druhou školou bolo gymnázium. Výber takéhoto typu škôl bol zámerný z dôvodu ciela a témy neskoršieho skúmania hodnoty vzdelania u študentov vysokých škôl. Ked'že žiaci stredných odborných škôl sú najmenšou skupinou žiakov stredných škôl pokračujúcou vo vysokoškolskom štúdiu, bol tento typ strednej školy z (pred)výskumu vylúčený. Žiaci stredných odborných škôl tak budú v interpretáciách a záveroch opomenutí. Rovnako tak sa výsledky netýkajú všetkých žiakov, ktorých vzdelanie bolo ukončené povinnou školskou dochádzkou.

Spoločne sme uskutočnili rozhovory v 15 takýchto skupinách. Počet žiakov v týchto skupinách bol 5-6, spolu 78. Výber ročníkov pre výskum bol tak isto podriadený danému cielu neskoršieho výskumu, a tak boli z každej triedy v danom ročníku vybraní žiaci v rovnakom pomere podla uváženia

3 Výskum so žiakmi stredných škôl bol predvýskumom k dizertačnej práci. 
učitela. Na vopred pripravené otázky odpovedal zväčša každý člen skupiny osobitne a následne sa o otázke diskutovalo medzi žiakmi, ktorí zdôvodňovali alebo rozširovali svoje odpovede. Koncepcia otázok sa odvíjala od výskumu hodnôt Schwartza (1987, 1992, 1999). Výskum hodnôt Schwartza sa odvíja z predpokladu, že hodnoty sú významnými motivátormi l'udského konania. Schwartz na základe tohto predpokladu vytvoril maticu s desiatimi individuálnymi hodnotovými doménami.

V rozhovoroch bol vytváraný obraz vzdelaného človeka ako nositela hodnôt a vzdelanie bolo teda vo výskume chápané ako zástupná hodnota inej hodnoty (vždy definovanej z matice hodnotových domén od Schwartza). Biele plátno, na ktoré sa tieto hodnoty mali premietat', bola maturita. (Maturita je dôležitá, pretože...) Tento obraz bol predkladaný na zhodnotenie žiakom stredných škôl. Hodnoty sa teda stali pre mňa v tomto prípade reprezentáciami reality, teda „relatívne ustálenými výsledkami subjektívnej a intersubjektívnej zdiel'anej transformácie reality a rovnako tak praktikami reprodukcie reprezentácií“ (Bočák, 2009, s. 100).

V rozhovoroch som tak prostredníctvom hodnôt vzdelania sledoval diskurz o vzdelaní, štúdiu a práci, ktoré boli objektmi samotného výskumu. Samotná analýza prebiehala kritickou analýzou diskurzu (critical discourse analysis $C D A^{4}$ ). Sledované boli diskurzívne praktiky žiakov, chápanie ich vlastnej pozície $\mathrm{v}$ diskurze a rámcovanie spomenutých troch hlavných pojmov $\mathrm{v}$ ich živote. Tým, že v niektorých otázkach sa odpovedalo postupne, boli odpovede posledných $\mathrm{v}$ rade mnohokrát spoločensky žiaduce, prípadne konformné s ostatnými spolužiakmi. Poradie odpovedania sa pri každej otázke menilo a vždy začínal odpovedat' ako prvý iný žiak. V konformných a sociálne žiaducich odpovediach bolo možné čítat' reflexiu súčasného diskurzu, na druhej strane $\mathrm{v}$ bezprostredných reakciách žiakov zase vlastný postoj k diskurzu. Sociálne žiaduce a konformné odpovede teda neboli diskriminované, slúžia skôr na vytváranie mapy diskurzu.

\subsection{Bohatstvo, úspech a vzdelanie}

Výchova, vzdelanie a vzdelávanie boli v minulosti reprezentované ako oblast’ kultúrnej reprodukcie spoločnosti či spoločností. Vedomosti a znalosti sa posúvali z generácie na generáciu za účelom ich použitia u tej mladšej generácie, prípadne aj na inovácie riešení, ale jednoznačný táah na niečo, čo by

4 Vychádzajúc najmä z prác N. Fairclougha $(1992,1995,1999)$ s L. Chouliaraki. 
sme mohli nazvat' progresizmom neexistoval. $V$ posledných desat'ročiach, ale môže sledovat’ odpájanie vzdelania a vzdelávania od diskurzu reprodukcie kultúry, pri ktorej by marxisti hned' mohli zareagovat' na jej duálne spojenie s reprodukciou socioekonomickou. Inštitucionálna školská výchova a vzdelávanie sú dnes spojené a posunuté do sféry ekonomickej a v tejto sfére sa okolo nich buduje aj diskurz s vlastnými pravidlami. Toto je vlastne problém, na ktorý upozorňujú práve Peters a Besley (2006).

Žiaci stredných škôl pracujú úplne prirodzene s dualizmom vzdelanie - práca a zarad'ujú vzdelanie do kontextu hospodárstva spoločnosti. Neuvažujú o vzdelaní ako o reprodukčnom mechanizme spoločnosti. Nevidia poznatky, ktoré sa v škole učia v širšej dimenzii historického kontextu. Dualizmus vzdelanie práca prináša so sebou aj dualizmus potrebnosti a nepotrebnosti poznatkov. Predmety, ktoré sa netýkajú budúceho štúdia žiaka, sú chápané žiakmi ako nadbytočné či zbytočné. Vzdelanie je pre nich predovšetkým získanie kompetencií k práci. To sa ukázalo aj pri diskusii o hodnotách vzdelania. Hodnoty konzervativizmu spojené so vzdelaním neboli chápané ako patriace ku sebe, napríklad morálka človeka nebola chápaná ako naviazaná na učenie sa, ale na vnútorné presvedčenie človeka, ktoré bolo spájané s vrodenými schopnostami človeka, prípadne s jeho sociálnym okolím.

Zodpovednost' ako osobitná kategória, ktorú bežne zarad'ujeme medzi cnosti jednotlivca, medzi akési sociálno-kultúrne reprezentácie vhodných vlastností jednotlivca, bola v súvislosti so vzdelaním taktiež zarad'ovaná do ekonomickej dimenzie. Zodpovednost' vzdelávat' sa a byt' vzdelaný existuje v rámci diskurzu vzdelávania, ako o ňom hovorili žiaci vo vzt’ahu ks vlastnej budúcnosti videnej cez prizmu práce. Zodpovednost' je síce chápaná ako etická kategória, ale zanesená do zodpovednosti za vlastný životný osud a možnost' s vlastným životom narábat' a riadit' ho. Žiaci hovorili o zodpovednosti spojenej s individualizmom, nie o zodpovednosti naviazanej na kolektívny záujem. V tomto kontexte mat' osud vo vlastných rukách, znamená mat' také množstvo prostriedkov, aby jednotlivec mohol slobodne rozhodovat' o cestách, na ktoré sa vyberie.

Čo je podla vás vzdelanie? (otázka výskumníka) Vedomosti, ktoré dokážeme využit'. (bezprostredná odpoved' žiačky z OA)

Individuálna využitel'nost' všeobecných znalostí. Toto je jedna z charakteristík diskurzu o vzdelaní a vzdelávaní u žiakov. Vedie sa debata o privatizácii vzdelávania v globálnom meradle. Ako na Slovensku, tak ani v Čechách sa ešte 
nepristúpilo $\mathrm{k}$ akejsi forme spoluúčasti študentov na financovaní vlastného vzdelávania na vysokých či stredných školách plošne, teda v školách financovaných zo štátneho rozpočtu. Takýto systém je postavený na predpoklade, že ak jednotlivec chce využit' naučené vedomosti pre vlastné účely, mal by si za ne zaplatit'. Ako je však možné vidiet' v našich podmienkach, žiaci uvažujú o vzdelávaní a vzdelaní v rámci rovnakého diskurzu, avšak v „modrom“ odtieni. Vedomosti (zručnosti, kompetencie atd') chápu ako nástroje, pomocou ktorých sa môžu dopracovat' k uspokojeniu vlastných záujmov. Spoločné dobro - všetko to, čo dodnes vieme o svete, v ktorom žijeme, inak povedané vedenie - je pre nich reprezentované ako objekt, z ktorého možno čerpat'. Tento objekt nie je chápaný ako živý organizmus, ktorý je živý jednak tým, že poskytuje niečo všetkým a zároveň do neho všetci spoločne prispievajú.

V spomenutej forme tak môže vedenie vystupovat' a byt' reprezentované ako súčast' kultúry, pretože na jednej strane poskytuje modely a na strane druhej nové modely integruje do seba. Práve chápanie vedenia ako staticky daného všetkým, pričom záleží len na jednotlivcovi, ako vedenie využije a nepochopenie jeho povahy ako živého organizmu stojí za dnešným videním vzdelania a vzdelávania u žiakov stredných škôl. Nejde tu len o utilitárne využitie univerzálnych znalostí zo strany učiacich sa, ide o zmenu povahy celého systému vzdelávania.

Žiaci teda vidia vzdelávanie a vzdelanie ako systém, z ktorého je možné čerpat', čo je možné demonštrovat' aj na spôsobe chápania spojenia vzdelania a subjektívne chápaného (ekonomického) bohatstva. Individuálna ekonomická prosperita je vo videní žiakov priamo napojená na vzdelanie. Na debatu, ktorá sa vedie na túto tému, však netreba nazerat' ako na debatu medzi idealizmom (vzdelanie kultúrne pozdvihuje jednotlivca samé o sebe) a utilitarizmom (vzdelanie slúži nejakému účelu). Existuje viacero dôvodov, vybral by som však jeden a to ten, ktorý považujem za najdôležitejší. Takto vedená debata by ukazovala na rozpoltenost' pojmu vzdelanie a vzdelávanie do dvoch diskurzov a to kultúrneho a ekonomického. Žiaci stredných škôl však uvedené pojmy nechápu ako patriace do dvoch diskurzov. Vzdelanie a vzdelávanie je pre nich jednoznačne zaradené do diskurzu ekonomiky. Vzdelanie ako kultúrne pozdvihnutie jednotlivca je úprimne prežívané ako získanie poznania, ktoré je však potrebné účelne použit’ v ekonomických aktivitách jednotlivca. Veda, ktorá slúži aj na rozvoj vzdelanosti, by pravdepodobne taktiež nebola spojená s kultúrnou reprodukciou znalostí a ich rozvojom, ale predovšetkým s ekonomickým rozvojom. 


\subsection{O zaklínadlách a mantrách}

Názov tejto podkapitoly vznikol zo zistenia, akým spôsobom je uplatňovaný diskurz neoliberalizmu v rozprávaní žiakov. Neexistuje rozdiel medzi žiakmi našich dvoch škôl vo veci presvedčenia o tom, kto a aký je úspešný človek. Je šikovný a vie sa presadit'. Tieto dve charakteristiky definujú úspešného. Otázky, na ktoré sme dostávali odpovede od školákov, smerovali k hodnotám, ktoré sú cenené v našej spoločnosti ako bohatstvo, prestíž, pohodlný konzumný život, múdrost', bezpečnost', vzdelanie. ${ }^{5}$

No možno o tom, že ako sa vie človek presadit', aký je šikovný a o tých príležitostiach. (Martina - $\mathrm{OA}^{6}$ ); Závisí to naozaj od toho, ako sa viete presadit'. Sú l'udia, ktorí majú $v$ hlave vel'a, ale ked' nevedia určité veci, ked' nevedia komunikovat's l'ud'mi, tak im to nepomôže. (Andrea-OA); No zarobit'sa dá všade, ked'ste šikovný, kde sa viete presadit'. (Jaro - $\mathrm{G}^{7}$ ); ...záleží od človeka ako sa dokáže presadit', môže sa mat' lepšie aj ten s tou strednou školou. (Soňa - OA); ...ako sa človek vie presadit', podl'a mňa je to strašne dôležité, aký má ten človek to svoje vystupovanie. Že hned' na prvý pohl'ad vie zaujat', že je sebavedomý, cielavedomý... Nie, že niekto príde, nevie čo má povedat', je ticho a čaká. Každý si musí íst' sám za sebou, nespoliehat'sa na druhých, že mu pomôžu, ale pomôže si sám. (Ad’a - OA)

Hodnoty - sociálne štruktúrované a reprezentované ciele úspechu, sú chápané žiakmi ako vyhradené pre tých šikovných a tých, čo sa vedia presadit'. Za nijakou hodnotou sa nedostane človek bez toho, aby bol šikovný alebo lepší ako ostatní. Hodnoty, ku ktorým smerovali odpovede o tom, čo je to vlastne úspech, nesúviseli úzko s profesiou ako reprezentantom finančného zabezpečenia, alebo s prácou, ktorú by chceli vykonávat'. Hodnoty variovali od konzervatívnych hodnôt rodiny a detí, vlastného domu až po hodnoty autonómie, kde žiaci zdôrazňovali dôležitost' zmeny a nie silného viazania sa na trvalú profesiu, ale aj na rodinu.

Podnikavost' a sútaživost' s inými, to sú charakteristiky, ktoré prinesú človeku životný úspech. Oba vel'mi často skloňované pojmy šikovnosti a presadenia sa však ani raz neboli vysvetlené ako žiaduce správanie, ktoré by malo jednotlivé postupné kroky. Pojmy boli skôr používané ako zaklínadlá, mantry či označenia inštrumentálnych postupov v súčasnosti, ktoré v prípade, že jednotlivec dodržiava, nemôže neuspiet'. Akonáhle sa v diskusii vyskytla

\footnotetext{
Otázky boli viac špecifické, pýtali sa napríklad na to, či je vzdelaný človek bohatý alebo či sa môže cítit' viac bezpečne ako človek nízko vzdelaný.

OA - obchodná akadémia

7 G-gymnázium
} 
medzera vo vysvetlení úspechu, napríklad napriek tomu, že vyššie príjmy majú vo všeobecnosti ludia s vysokoškolským vzdelaním, ako je možné, že aj ludia so stredoškolským vzdelaním majú mnohokrát vyššie príjmy ako predchádzajúca skupina, bola odmietnutá. Vysvetlenie spočívalo vždy v tom, že niektorí boli šikovní a lepšie sa v živote presadili. Samotný status vysokoškolského titulu bol odmietaný ako relevantný pre úspech v prípade, že nie je spojený so šikovnost'ou a sebapresadením. Relevantné pre úspech v živote sa ukázalo aj získanie bohatstva zdedením či pracovné miesto získané korupciou, či klientelizmom, pričom ani jedna zo stratégií nebola jednoznačne odmietnutá. Boli skôr chápané ako „kultúrne“ paralelné spôsoby dosahovania úspechu jednotlivca, nie teda ako všeobecne kultúrne neprijímané.

Vysokoškolské vzdelanie je druhá mantra, ktorou sa žiaci často zaklínali. Samotné vysokoškolské vzdelanie skrýva v sebe takú hodnotu, ktorá prinesie človeku životný úspech.

Podla mňa je to dost' na tej šikovnosti, ako sa človek presadí, tá vysoká škola by nám to tak ulahčila. (Jana - OA); ...vysoká škola nezaručí tol'ko. Otázka: Takže je to zase o šikovnosti? Odpoved': No, ale tá výška by mi pomohla dobre. (Bebe - OA); Podl'a mňa, už len ked' máte titul, sa na Vás ludia inak pozerajú. (Zuzana - G); Tá výška je krok k tomu, aby sme mohli zarábat' väčšie peniaze, aby sme sa mali lepšie v živote. (Andrea - G); Ja si myslím, že l'udia si robia VŠ preto, že musia. Tá maturita už neznamená v podstate nič. Sú aj výnimky, že áno chcem íst' na vysokú, ale človek s tou maturitou už dnes neznamená nič. (Veronika - OA)

Spoločné zdôvodnenie významov štúdia na vysokej škole je jednotné, a tým je úspech v živote. Výborne túto dimenziu vzdelávania vystihli Nairn a Higgins (2007, s. 264, kurzíva - autor):

V tomto neoliberálnom diskurze je identita učiaceho sa chápaná mladými l'ud’mi ako nadobudnutá v škole a „praxi“ po škole cez t’ažkú prácu a vhodné správanie sa. Identita úspešného pracujúceho je chápaná tak, že sa na tieto nadobudnuté kvalifikácie pozerá na pracovnom trhu, a tak sa investície do vzdelania vyplatia v zmysle individuálnej sily na tomto trhu.

Naháňačka za vysokoškolským vzdelaním je tak vlastne naháňačkou za renomé či reputáciou, jednoducho za tým, čo Collins (1979) nazýva credentials. Netreba zabúdat' na to, že úspech v živote má množstvo dimenzií, ktoré sú mu pripisované a na základe ktorých je chápaný ako životný úspech. Vysokoškolské vzdelanie sa jednak spája s prestížou, pretože absolvent nadobúda diplom a s ním aj kultúrny kapitál (inštitucionalizovaný a vtelený). Vysokoškolské vzdelanie je u žiakov skúmaných 
stredných škôl vždy spájané aj s vyšším príjmom, ktorý je, ako už bolo povedané, podmienený šikovnostou. Žiaci rozmýšlajú v tomto prípade zjavne investične. Snažia sa maximalizovat' investície pre maximálne zisky a zároveň stlačit' riziko čo najnižšie. Najzaručenejším modelom životného úspechu je tak vysokoškolské vzdelanie, šikovnost' a presadenie sa.

\subsection{Vysoká škola a nevyhnutnost'študovat'}

Vysokoškolské vzdelanie je v rozprávaní žiakov chápané značne utilitárne. Na jednej strane sú tí, ktorí vidia vo vysokoškolskom štúdiu investíciu do seba v podobe poznatkov či zručností, na druhej strane stoja tí, ktorí chápu vysokoškolské vzdelanie ako „titul“, teda obyčajný nástroj alebo investíciu do kultúrne rozpoznávanej formy či dokladu úspechu.

Mňa hlavne láka titul. Akože vel'mi. ... (Ad’a - OA); Mňa štúdium moc nebaví, takže ja by som najradšej išla robit', ale na výšku už teraz musím íst'v dnešnej dobe.... Myslím si, že ked' má človek titul, tak ho uprednostnia, ako ked' má iba strednú a maturitu. A mne je v podstate jedno, aj čo vyštudujem.. (mlčanie) Mne je to úplne jedno... (Martina - OA)

Snaha o vysokoškolské vzdelanie je aj hrou o istotu. Význam vysokoškolského vzdelania však bol chápaný mierne odlišne v školách, kde sme uskutočnili výskum. V obchodnej akadémii bola chápaná vysoká škola a jej absolvovanie ako pokračovanie strednej školy, teda vzdelávania sa v snahe o uplatnenie sa. Inak povedané, vzdelávanie sa pre úspech v živote. Žiaci gymnázia taktiež chápali vysokú školu ako nevyhnutnú pre úspech v živote, ale s tým rozdielom, že výber vysokej školy je výzva a zároveň dozreté rozhodnutie, ktoré bude mat' vyústenie v jej absolvovaní. Pre tých prvých je vysokoškolské vzdelanie nutnostou pre úspech (aj s premáhaním sa), zatial' čo pre tých druhých je to výzva na dosiahnutie úspechu. Tieto rozdiely vyplývajú z rozdielnych stratégií vzdelanostných ciest, ktoré sú podmienené, ako sa domnievam, socioekonomicky.

Práve tlak na výber, ktorým je charakteristická dnešná doba, je viditelný na oboch typoch škôl, ale na obchodnej akadémii dostáva odtieň rýchlo sa navracajúcej investície, na gymnáziu má zase odtieň bezpečnej zvažujúcej investície. Na pozadí Beckovej (2004) Rizikovej spoločnosti, v ktorej žijeme, je teda obchodná akadémia bezpečná investícia do vzdelania z dôvodu možnosti okamžitého prispôsobenia sa zmeneným životným podmienkam. Prehlad v účtovníctve a základy ekonómie dávajú, podla žiakov obchodnej akadémie, im samotným kvalifikáciu okamžite po strednej škole pracovat', ak 
by to bolo nevyhnutné vzhladom na rodinnú a/alebo ekonomickú situáciu. Gymnázium je taktiež bezpečná investícia do vzdelania, ale z iného dôvodu. Okrem toho, že demonštruje status rodiny, necháva všetky možnosti vysokoškolského vzdelania otvorené. Ani jeden typ školy nebol vo výskume „čistým typom" toho-ktorého chápania vysokoškolského vzdelania, príslušné vzorce rozhodovania sa o výbere strednej školy sa však ukazovali vždy častejšie na dotknutom druhu strednej školy.

\subsection{Diskurz výberu a uplatnenia}

Jedným zo znakov neoliberálnej guvernmentality je aj výber. Otázkou sa tak pre mňa stalo chápanie vlastnej pozície $\mathrm{v}$ diskurze uplatnenia sa na pracovnom trhu u žiakov. Tlak na výber znamená a hovorí o nutnosti urobit' „správne rozhodnutia“ pre „úspech v živote“. Výber ako taký však nebol žiakmi zdôrazňovaný, pokial' hovoríme o nutnosti zvažovat' a urobit' krok. Predstava úspechu bola chápaná vel'mi jednoducho, ako vyberanie si len medzi stupňom vzdelania, ktorý chce jednotlivec dosiahnut' alebo by ho mal dosiahnut', pokial' chce maximalizovat' šance na svoj úspech. Výber študijného programu či vysokej školy nebol zdôrazňovaný ako dôležitý pre úspech v živote. Napriek tomu, že študijné programy, ktoré ešte v nedávanej minulosti rezonovali ako „kultúrne lukratívne“, a to medicína, právo či ekonómia, neboli predominantne žiakmi zdôrazňované ako dôležité či najvhodnejšie pre vysokoškolské štúdium. Priama otázka na to, či je pre žiakov prijatel'nejšie študovat' to, čo ich zaujíma a čomu sa chcú venovat' alebo to, v čom vidia istotu (ekonomického a statusového) úspechu v budúcnosti, bola v každej jednej skupine zodpovedaná rovnako. Žiaci chcú študovat' to, čo ich zaujíma a čomu sa chcú venovat'.

Sloboda výberu, tlak na výber a rozhodnutie sa tu spojili s presvedčením o vnútornej jednote a harmónii jednotlivca. Teda nedá sa povedat', že by boli prevzaté dogmy neoliberalizmu o výlučne racionálnom správaní a zvažovaní investícií a výnosov. Práve naopak, tieto sú potlačené na úkor videnia života ako projektu úspechu, ktorý je projektom štastia (a to nie je možné dosiahnut' bez akéhosi vnútorného zmieru). Žiaci sa očividne pri výbere vysokej školy nerozhodovali úplne utilitárne, napríklad na základe výberu štúdia, ktoré umožní vykonávat' finančne výnosné zamestnanie či profesiu. Vzdelanie pre nich musí byt' „konzumovatel'né“, prítažlivé a hlavne vnútorne napĺnajúce. Vzdelanie je skôr reprezentantom žiadostivosti po niečom, ako odopieraním si pôžitku pre jeho dosiahnutie v budúcnosti. Efektívne zarábajúci či úspešný 
človek musí byt' aj vnútorne spokojný s vlastným výberom, rozhodnutiami a životnými krokmi.

Diskurz uplatnenia, ktorý je vedený žiakmi, čítam ako diskurz, v ktorom žiaci nehladajú ani tak zamestnanie, alebo neexistuje tam tlak na to, nájst' si také zamestnanie, ktoré bude ekonomicky čo najvýnosnejšie. Uplatnenie sa znamená niečo iné. Uplatnenie sa odkazuje ku vykonávaniu niečoho, čo je možné považovat' za potrebné $\mathrm{v}$ dnešnej spoločnosti, ale čo je zároveň obmedzené $\mathrm{v}$ diskurze neoliberalizmu na uplatnenie sa na pracovnom trhu. (Najčastejšie spojenie slov uplatnenie sa je so slovom prax.) Cynicky sa tak dá poznamenat', že to nie je vzrušenie z inovácií, ktoré žiaci hladajú, ale istota príjmu a istota plateného miesta. Žiaci tak síce hl’adajú cestu, ako si nájst' príjem, ale zároveň musia mat' pocit naplnenia z vykonávanej práce.

\subsection{Diskurzívny pár vzdelanie - práca}

Je dost' možné, že sa nepodarilo odhalit' triednu podmienenost' skúmaného javu. Pravdepodobne kvôli tomu, že výber škôl bol obmedzený. Aj staršie výskumy zo zahraničia (napr. Willis, 1977; LeCompte, 1978) ukazujú, že diskurzívny pár vzdelanie a práca je prítomný ako skryté školské kurikulum a zároveň ako taký má význam pri triednej reprodukcii.

Kde by ste chceli byt' o 7 rokov? Čo by ste chceli robit'? (nasledujú rôzne odpovede) Je zvláštne, že nikto z vás nespomenul, že by už chcel mat' rodinu a s ňou i deti. (komentár výskumníka) No my sme si mysleli, že sa bavíme o vzdelaní. (bezprostredná odpoved' žiačky z OA)

Brown (2003) hovorí, že neoliberálna racionalita sa nesústred'uje primárne na ekonomiku, ale zahŕňa rozpínajúce sa a rozširujúce hodnoty trhu do všetkých inštitúcií a sociálneho diania. Úspech, presadenie sa, bohatstvo, moc, dosiahnutie statusu, možnost' vysokého konzumu, d'alej individuálna vol'ba a zodpovednost' subjektu, konkurencia či pozitívne vnímanie nerovností (Moss, 2009) a rovnako tak aj transformácia l'udí na produktívnych ekonomických podnikatel'ov s ich vlastnými životmi (Davies \& Bansel, 2007, s. 248) sú obsahmi, ktoré nesie v sebe dnešná podoba inštitucionálneho školského vzdelávania.

Žiaci vybraných stredných škôl rozmýšlajú o vzdelaní v rámci diskurzu ekonomiky a práce. Je pre nich vel'mi prirodzené sledovat' túto líniu rozmýšl'ania o svojom živote, $v$ ktorom je projekt vzdelávania zároveň projektom prípravy do práce. Cynizmus žiakov, tak charakteristický pre súčasné inštitucionálne 
vzdelávanie, vyplýva práve z presvedčenia o formálnej potrebe vzdelania. Ako som už napísal vyššie, deliaca línia medzi idealistickým a utilitaristickým pohladom na vzdelanie tkvie $\mathrm{v}$ jej ukotvení v diskurze ekonomiky a cynizmus môžeme čítat' ako extrémnu polohu utilitarizmu. Žiak idealista vie, že byt' vzdelaný je prostriedok a predpoklad pre prácu, zároveň nikdy nevie, čo sa mu v tej práci zo školských čias môže zíst’. Utilitarista nevidí vzdelanie ako prostriedok a predpoklad, ale ako podmienku zamestnávatela. Vzdelanie v humboltovskom význame slova je, ako svojbytný diskurz medzi žiakmi, mŕtve.

Evetts (2013) vo svojej štúdii ukazuje, že profesia a profesionalita sa postupne počas niekol'kých desat'ročí inštitucionalizovali vo verejnom diskurze a začali byt' spájané s prislúchajúcim platom, statusom a mocou, ktoré patria k danej profesii a úrovni profesionality. Profesia a profesionál sa spájajú s úrovňou vzdelania či odbornej prípravy. Jednou z myšlienok Kaščáka a Pupalu (2012) v charakterizovaní detí zlatých golierov je práve ich vyrastanie vo svete, v ktorom existujú očakávania o ich uplatnení. Íst’ si za uplatnením na pracovnom trhu, znamená sledovat' cestu inštitucionalizovaných pracovných pozícií - profesií. Deti vyrastajú v kultúre ideológie profesionality a profesionalizmu. Práve tento aspekt chápania vzdelania bol čitatel'ný aj v rozhovoroch so stredoškolákmi a stredoškoláčkami.

Práca a vlastné vzdelanie sú si vzájomným predpokladom v chápaní žiakov. Prácu je vel'mi t’ažké získat', ak človek nemá adekvátne vzdelanie, súdili žiaci. Žiaci zároveň často prízvukovali, že je problematické vykonávat’ adekvátnu prácu, ak jednotlivec nemá prislúchajúce vzdelanie. Zároveň boli za vhodnú prácu považované len pracovné miesta, ktoré by sme mohli definovat' ako profesie (s prislúchajúcim vzdelaním). Práca a profesia splývajú v jedno, ked' sú zaradené do skupiny pojmov zastrešenej pojmom vzdelanie. Na úrovni diskusie prepájania vzdelávania a práce a vzdelávania a profesie ide $\mathrm{v}$ diskurze o pojmy s totožným postavením. Práca sa tak obmedzuje na prácu ako výkon určitej profesie a nie na l'udskú činnost'. Toto je jedným z d’alších bodov, prečo sú úzko prepojené vzdelávanie a práca. Vzdelanie je dôležité ako nástroj na vykonávanie profesionálnej práce, teda práce so statusom.

Nie je potrebné hovorit' o prehnaných očakávaniach u žiakov, ked' spomíname ich život po škole. Tie sú pravdepodobne len symptómom a maturita je len hranicou medzi dvoma svetmi. Možno závažnejšie je obmedzené chápanie práce na sociálne a kultúrne štruktúrované profesie. Procesy, ktoré inštitucionalizovali pojmy profesia a profesionalita vo verejnom diskurze, nie je 
potrebné obmedzovat’ na súčasnú podobu kapitalizmu. Som toho názoru, že napriek všetkému sú tieto procesy vo svojich dnešných konsekvenciách stopovatel'né aj do socialistického Československa.

\section{Záver}

Inštitucionálne vzdelávanie sa $\mathrm{v}$ posledných desat'ročiach stalo významnou formou, do ktorej vkladáme obsahy svojho životného úspechu. Vzdelanie samotné je pre mnohých len obtažujúca cesta, ktorú si treba prejst' za vlastnými ciel'mi, pre iných zase cesta síce zaujímavá, ale možnosti po jej prejdení sú aj pre nich prítažlivejšie ako ona samotná. Do tretej skupiny patria tí, pre ktorých je vzdelávanie sa cestou zaujímavou a možnosti, ktoré ponúka vzdelanie $\mathrm{v}$ inštitucionalizovanej podobe sú len slabými motivátormi. Vzdelanie je možné považovat' za cestu za niečím. Za dobrým a pohodlným životom, za úspechom, za bohatstvom, za poznaním. Či už je vzdelanie chápané ako poistenie alebo výtah (srov. Keller \& Tvrdý, 2008), nezáleží, pretože je to nástroj na dosiahnutie niečoho d'alšieho. Významnou sa tak stala do značnej miery forma namiesto obsahu.

Foucault (2008, s. 252-253) hovorí, že koncepcia homo economicus je styčným bodom medzi štátom a individualitou. Žiaci poznajú kultúrne znaky toho, čo môžeme týmto pojmom označit’ a uplatňujú ich v rozprávaní o práci, nutnosti vzdelávania sa a štúdia. Homo economicus vlastne funguje ako očakávané správanie sa jednotlivca $v$ živote. Žiaci stredných škôl uplatňovali práve predstavu úspešného človeka s charakteristickými rysmi vo svojom rozprávaní o sebe a vlastnom uplatnení sa. K rovnakým záverom prichádzajú aj Bialostok a Kamberelis (2012) a ukazujú, že ideológia neoliberalizmu funguje na mikrorovine l'udského premýšlania o sebe a druhých. Vo výskume, kde sledovali školskú triedu, identifikovali prvky neoliberalizmu ako zdôrazňovanie individualizmu, reflektovanie vlastných životov, evaluáciu a marketizáciu seba cez sebarealizáciu a sebaaktualizáciu. Identifikovali tak isto prvky sebakontroly a usmerňovania vlastného správania sa pre budovanie vlastnej zodpovednosti, ktorá má smerovat' k zvládnutiu rizík. Vôbec nie menej dôležité je názorné ukázanie, ako cez stratégie vol'by vidia deti svoj život ako racionálny projekt.

Ako som sa pokúsil ukázat', vo vyjadreniach žiakov stredných škôl môžeme nájst' znaky, ktoré sú charakteristické pre súčasný neoliberálny diskurz, ktorý existuje vo vzdelávaní. Základnými diskurzívnymi bodmi, o ktoré sa žiaci 
najčastejšie opierali vo vzt'ahu ku vzdelaniu a práci, boli šikovnost', presadenie sa a vysokoškolské vzdelanie a prepájanie práce a vzdelania. Šikovnost', presadenie sa a vysokoškolské vzdelanie dokážu človeku zabezpečit', podla presvedčenia žiakov, úspešný život. Bližšie vysvetlenie tieto pojmy u žiakov nemali. Fungovali len vo svojej ideálnej podobe. Zaradenie týchto pojmov do konsekvencií a kontextov prinášalo v rozprávaní vždy rozpaky, pretože ich žiaci nevedeli bližšie vysvetlit', a to práve z povahy veci samotnej, ked'že tieto pojmy sú zaradené do diskurzu neoliberálneho chápania človeka ako homo economicus. Žiaci rozmýšlajú o svojom d’alšom živote ako o živote subjektu homo economicus. Predpokladajú, že sa od nich očakávajú výkony, schopnosti a skúsenosti. S týmto predpokladom potom prichádzajú k rozhodnutiam o tom, kam sa bude uberat' ich život po maturite. $V$ týchto bodoch zároveň môžeme vidiet' kultúrne dimenzie a kontexty, v ktorých sa dnes vzdelávanie nachádza. Peters a Besley (2006) nechcú definovat' súčasné vzdelávanie ako akéhosi otroka ekonomických tlakov, ako som už skôr napísal. Celý problém vidia ako kultúrno-ekonomický. Takto sa dá charakterizovat' aj súčasná povaha rozmýšlania žiakov stredných škôl o budúcom živote. Rozmýšl'anie o ukončení strednej školy sa pohybuje v kultúrnych kontextoch inštitucionalizujúcej sa kultúry vzdelávania s rôznymi množstvami prímesí neoliberálnej guvernmentality. Inak povedané, je úplne zrejmé, že ekonomický diskurz, na niektorých miestach viac, na niektorých menej, kolonizuje kultúru, ktorá je však pre zmeny otvorená.

\section{Podakovanie}

Autor chce pod’akovat' recenzentom za kritické poznámky a odporúčania, ktoré pomohli pri úpravách štúdie. Rovnako tak je potrebné pod’akovat' žiakom a vedeniu škôl: Gymnázium, Hlinská 29, Žilina a Obchodná akadémia, Vel'ká okružná 32, Žilina za ústretovost' a dôveru pri výskume.

\section{Literatúra}

Apple, M. (1990). Ideology and curriculum. New York: Routledge.

Amthor, R. F., \& Metzger, S. A. (2011). Neoliberalism, globalization, and the American universities in Eastern Europe: Tensions and possibilities in 'exported' higher education. Globalizations, 8(1), 65-80.

Baltodano, M. (2012). Neoliberalism and the demise of public education: the corporatization of schools of education. International Journal of Qualitative Studies in Education, 25(4), 487-507. 
Bansel, P. (2007). Subjects of choice and lifelong learning. International Journal of Qualitative Studies in Education, 20(3), 283-300.

Beck, U. (2004). Riziková společnost. Na cestě k jiné moderně. Praha: SLON.

Bernstein, B. (1971). Class, code and control: Volume 1 - Theoretical studies towards a sociology of language. Oxon: Routledge \& Kegan Paul.

Bernstein, B. (1977). Class and pedagogies: Visible and invisible. In B. Bernstein (Ed.), Class, codes and control III. (s. 116-156) London: Routledge and Kegan Paul.

Bialostok, S., \& Kamberelis, G. (2012). The play of the risk, affect, and the enterprising self in fourth-grade classroom. International Journal of Qualitative Studies in Education, 25(4), 417-434.

Bočák, M. (2009). Diskurz: neurčitá cesta kulturálnych, mediálnych a komunikačných štúdií do centra svojho záujmu. Kultura - médiá - komunikace, 1(1), 117-146.

Bourdieu, P., \& Passeron, J-C. (1977). Reproduction in education, society and culture. London: Sage Publications.

Bourdieu, P. (1998). Teorie jednání. Praha: Karolinum.

Brown, W. (2003). Neo-liberalism and the end of liberal democracy. Theory \& Event, 7(1). Dostupné z http://muse.jhu.edu/

Brown, P., \& Lauder, H. (2006). Globalisation knowledge and the myth of the magnet economy. Globalization, Societies and Education, 4(1), 25-57.

Collins, R. (1979). The credential society. New York: Academic Press, Inc.

Davies, B., \& Bansel, P. (2007). Neoliberalism and education. International Journal of Qualitative Studies in Education, 20(3), 247-259.

Evetts, J. (2013). Professionalism: Value and ideology. Current Sociology, 61(5-6), 778-796.

Fairclough, N. (1992). Discourse and social change. Cambridge: Polity Press

Fairclough, N. (1995). Critical discourse analysis: the critical studies of language. London: Longman.

Ho Mok, K. (2010). When state centralism meets neo-liberalism: managing university governance change in Singapore and Malaysia. Higher Education, 60(4), 419-440.

Holborow, M. (2012). Neoliberalism, human capital and the skills agenda in higher education the Irish case. The Journal for Critical Education Policy Studies, 10(1), 93-111.

Chouliaraki, L., \& Fairclough, N. (1999). Discourse in late modernity: rethinking critical discourse analysis. Edinburgh: Edinburgh university press.

Kaščák, O., \& Pupala, B. (2010). Neoliberálna guvernmentalita v sociálnom projektovaní vzdelávania. Czech Sociological Review, 46(5), 771-799.

Kaščák, O., \& Pupala, B. (2011). Neoliberalizmus vo vzdelávaní: pät’ obrazov kritických analýz. Pedagogická orientace, 21(1), 5-34.

Kaščák, O., \& Pupala, B. (2012). Škola zlatých golierov. Vzdelávanie v ére neoliberalizmu. Praha: SLON.

Keller, J., \& Tvrdý, L. (2008). Vzdělanostní společnost? Chrám, výtah a pojištovna. Praha: Sociologické nakladatelství.

Lakes, R. D. (2008). The neoliberal rhetoric of workforce readiness. Journal for Critical Education Policy Studies, 6(1), 335-351.

Lambeir, B. (2005). Education as liberation: The politics and techniques of lifelong learning. Educational Philosophy and Theory, 37(3), 349-356. 
LeCompte, M. D. (1978). Learning to work: The hidden curriculum of the classroom. Anthropology and Education Quarterly, 9(1), 23-37.

Moss, P. (2009). There are alternatives! Markets and democratic experimentalism in early childhood education and care. Hague: Bertelsmann.

Nairn, K., \& Higgins, J. (2007). New Zealand's neoliberal generation: Tracing discourses of economic (ir)rationality. International Journal of Qualitative Studies in Education, 20(3), 261-281.

Nussbaum, M. (2010). Not for profit: Why democracy needs the humanities. Princeton: Princeton Unviersity Press.

Olssen, M., \& Peters, M. A. (2005). Neoliberalism, higher education and the knowledge economy: From the free market to knowledge capitalism. Journal of Educational Policy, 20(3), 313-345.

Olssen, M. (2006). Understanding the mechanism of neoliberal control: Lifelong learning, flexibility and knowledge capitalism. International Journal of Lifelong Education, 25(3), 213-230.

Peters, M. A., \& Besley, T. (2006). Building knowledge cultures: Education and development in the age of knowledge capitalism. Lanham: Rowman \& Littlefield Publishing Group.

Pierce, C. (2012). The promissory future(s) of education: Rethinking scientific literacy in the era of biocapitalism. Educational Philosophy and Theory, 44(7), 721-745.

Resnik, J. (2012). The denationalization of education and the expansion of the international baccalaureate. Comparative Education Review, 56(2), 248-269.

Sancar, C., \& Sancar, M. (2012). Neoliberal mechnisation of education. TOJET: The Turkish Online Journal of Educational Technology, 11(3), 246-254.

Sassen, S. (2007). Sociology of globalization. New York: W. W. Norton \& Company.

Schwartz, S. H., \& Bilsky, W. (1987). Toward a universal psychological structure of human values. Journal of Personality and Social psychology, 53(3), 550-562.

Schwartz, S. H. (1992). Universals in the content and structure of values: Theoretical advances and empirical tests in 20 countries. In M. P. Zanna (Eds.), Advances in experimental social psychology (s. 1-65). San Diego: Academic.

Schwartz, S. H. (1999). A theory of cultural values and some implications for work. Applied psychology: An International Review, 48(1), 23-47.

Willis, P. (1977). Learning to labour - how working class kids get working class jobs. New York: Columbia University Press.

\section{Autor}

Mgr. Lukáš Bomba, PhD., Žilinská univerzita v Žiline, Fakulta humanitných vied, Katedra pedagogických štúdií, Univerzitná 8215/1, 01026 Žilina, , e-mail: lukas.bomba@fhv.uniza.sk 


\title{
The life after graduation or about values of education among high school students
}

\begin{abstract}
The paper presents meanings of the contemporary school education in the reflections of the secondary school students. The intent of the research was to pinpoint the high schools students' values of education and to search for the cultural dimensions of neoliberalism and the principles which govern the reason of pupils. At first, the author explains those parts of the theory of neoliberal govenmentality which are crucial for intepretation of the interviews with pupils. The author of this study discovers that fundamental concepts of discourse of life after graduation are skilfulness of an individual and assertion of individuality. These concepts are used for explanation of achievement of individuality. The author concludes that pupils do not consider the university as a place assess own life and to gain profit from study. The life after graduation is considered a project of a path to individual happiness and the life choice of university studies is subordinated to this reason.
\end{abstract}

Keywords: graduation, high schol, neoliberalism, neoliberal governmentality, university, studium, pupil

Thorová, K. (2014). Vývojová psychologie. Praha: Portál.

Publikace podává srozumitelný výklad vývoje člověka napříč celým životním cyklem. Zachycuje proměny lidské psychiky a chování od početí a prenatálního života až po umírání a smrt. Pohled na vývoj člověka je pojat moderně a vysoce aktuálně, témata jsou předkládána $v$ nových kontextech. $\mathrm{V}$ první polovině knihy najdeme podrobně zpracovaný vývoj sociální interakce, morálky, osobnosti, myšlení a řeči. Jedna z kapitol je věnována rozdílům mezi pohlavími. Druhá polovina knihy se zaměřuje na dílčí vývojová období. Zapracovány byly nové poznatky z neuropsychologie, genetiky a epigeneticky, zajímavé jsou výsledky výzkumů deklarující až těžko uvěřitelné kojenecké schopnosti zachytitelné jen díky moderním technologiím. Pozornost je věnována mj. rodičovství osob stejného pohlaví, detailně je rozpracována kapitola týkající se umírání a smrti. Publikace se opírá o vědecké poznatky, je bohatě vybavena odkazy na českou i zahraniční literaturu, rekapituluje kritické názory a snaží se čtenáře nasměrovat k otevřenému myšlení. Poukazuje na rozdílnost různých pohledů, varuje před př́lišnou unifikací a stereotypizací, věnuje se různým mylným přesvědčením a mýtům. Kniha ilustruje zajímavost a pestrost oboru, svou názorností a př́íklady ze života dokáže upoutat i zájem laiků. 